\title{
Perancangan Kontrol Pelacakan Lintasan untuk Robot Otonom Bergerak Beroda dengan Penggerak Diferensial
}

\section{(Design of Trajectory Tracking Controller for Differential-Drive Autonomous Wheeled Mobile Robots)}

\author{
Stephen I.C. Gulo ${ }^{1}$, Tua A. Tamba ${ }^{2, *}$
}

\begin{abstract}
Differential Drive Wheeled Mobile Robot (DDWMR) is a class of mobile robots which has been used in various applications due to its mobile abilities. One important issue in the development of DDWMR is regarding the design of control methods to ensure the DDWMR can move autonomously from initial to final poses. The main challenge in such an issue is the need to design a controller which respects the non-holonomic constraint of DDWMR movements. To address such a challenge, this paper proposes a control method which combines techniques in smooth reference trajectory generation and Lyapunov-based tracking control designs. In the proposed method, a reference trajectory that is represented as polynomial function is first generated to connect the initial and final poses based on some waypoints information between them. A feedback control law based on Lyapunov's stability method is then designed to help control the DDWMR in tracking the generated reference trajectory with minimum error. Numerical simulation results are given to illustrate the effectiveness of the proposed method.
\end{abstract}

Intisari-Robot bergerak beroda dengan penggerak diferensial (DDWMR) merupakan salah satu jenis robot bergerak yang telah digunakan di berbagai aplikasi karena kemampuan mobilitasnya. Salah satu isu penting dalam desain DDWMR adalah terkait penentuan metode kontrol untuk memastikan DDWMR tersebut dapat berpindah secara otonom dari satu pose awal menuju pose akhir tertentu. Tantangan utama pada isu tersebut adalah perlunya merancang pengontrol yang mampu mengatasi batasan non-holonomic pada pergerakan DDWMR. Untuk menjawab tantangan tersebut, makalah ini mengajukan suatu metode kontrol yang menggabungkan teknik perancangan lintasan halus dan teknik kontrol pelacakan lintasan berbasis analisis kestabilan Lyapunov. Pada metode yang diajukan, lintasan referensi berbentuk fungsi polinomial terlebih dahulu dirancang untuk menghubungkan pose awal dan akhir DDWMR yang diinginkan berdasarkan informasi titik jalan (waypoints) di antara keduanya. Sinyal kontrol umpan balik berbasis metode kestabilan Lyapunov kemudian dirancang untuk mengontrol DDWMR dalam mengikuti lintasan referensi yang diperoleh dengan error pelacakan seminimal mungkin.

${ }^{1}$ Prodi Sarjana Teknik Elektro (Mekatronika), Universitas Katolik Parahyangan, Jl. Ciumbuleuit no. 94, Bandung 40141, INDONESIA (tlp: 022-203-2655; fax: 022-203-1110; e-mail: 2017630031@student.unpar.ac.id)

${ }^{2} J u r u s a n$ Teknik Elektro, Universitas Katolik Parahyangan, Jl. Ciumbuleuit no. 94, Bandung 40141, INDONESIA (tlp: 022-2032655; fax: 022-203-1110; e-mail: ttamba@unpar.ac.id)

*Penulis korespondensi
Hasil simulasi numerik ditunjukkan untuk mengilustrasikan keandalan metode kontrol yang diusulkan.

Kata Kunci-Robot Bergerak Beroda, Penggerak Diferensial, DDWMR, Analisis Kestabilan Lyapunov, Batasan Nonholonomic.

\section{PENDAhuluan}

Robot bergerak beroda (Wheeled Mobile Robots, WMR) merupakan robot yang dapat bergerak dari posisi dan orientasi (pose) awal tertentu ke pose lain secara otonom tanpa bantuan eksternal (manusia) [1]. Kemampuan mobilitas WMR tersebut membuatnya banyak digunakan pada aplikasi kehidupan nyata, baik di lingkungan terstruktur maupun tidak terstruktur. Contoh penggunaan WMR antara lain untuk tujuan pelayanan medis, inspeksi, serta pengawasan terhadap area yang berbahaya [2]. Salah satu jenis WMR yang banyak dikembangkan hingga saat ini adalah jenis WMR dengan penggerak diferensial atau Differential Drive Wheeled Mobile Robot (DDWMR).

Salah satu isu penting dalam desain dan operasi DDWMR adalah terkait penentuan metode kontrol untuk memastikan DDWMR tersebut dapat berpindah secara otonom dari satu pose awal menuju pose akhir dengan mengikuti lintasan referensi tertentu. Tantangan utama dalam upaya kontrol tersebut adalah perlunya merancang pengontrol yang mampu mengatasi batasan non-holonomic pada pergerakan DDWMR. Pada dasarnya, batasan non-holonomic muncul akibat struktur mekanik dari robot yang tidak memungkinkannya untuk melakukan gerak translasi horizontal secara langsung pada arah yang tegak lurus dengan vektor arah putaran roda. Dalam hal ini, DDWMR harus melakukan urutan gerak berbentuk kurva jika ingin melakukan perpindahan secara horizontal pada arah sumbu putar dari roda. Sebagai akibatnya, DDWMR umumnya membutuhkan sekuen lintasan berbentuk kurva halus untuk berpindah dari satu pose ke pose lainnya [3].

Secara umum, struktur DDWMR terbagi menjadi tiga subsistem, yaitu struktur mekanis, aktuator, dan sumber tenaga. Pengontrolan DDWMR hingga kini telah dilakukan dengan berbagai pendekatan dengan mempertimbangkan kombinasi subsistem tersebut. Berdasarkan jenis model yang digunakan, pengontrolan dapat dilakukan berdasarkan model kinematika [4]-[10] atau dinamika [11]-[14] DDWMR. Terkait metode, beberapa algoritme kontrol yang telah diterapkan pada model DDWMR antara lain mencakup kontrol pelacakan lintasan dengan hierarchichal switching antara differential flatness dan proporsional-integral (PI) [4], 
kontrol pelacakan lintasan berbasis metode Lyapunov [5], kontrol torsi dinamik berbasis metode adaptive backstepping [15], serta kontrol cerdas berbasis jaringan saraf tiruan [16]. Selain itu, metode lain yang juga telah digunakan dalam melakukan pelacakan lintasan mencakup kontrol pelacakan lintasan dengan logika fuzzy [17], kontrol pelacakan lintasan dengan hierarchical fuzzy sliding-mode [18], kontrol pelacakan lintasan dengan pengontrol kinematika adaptif berdasarkan sistem jaringan saraf tiruan dengan basis fungsi radial [19], kontrol pelacakan lintasan berbasis sistem inferensi fuzzy terparameterisasi [20], dan metode backstepping berbasis fuzzy sliding-mode [21].

Untuk implementasi operasional secara otonom, DDWMR perlu dirancang agar memiliki komponen perencana lintasan (path planner) yang berfungsi mendesain lintasan referensi yang akan diikuti ketika bergerak dari pose awal menuju pose akhir. Perancangan lintasan referensi tersebut pada dasarnya harus tetap memperhitungkan batasan non-holonomic pada DDWMR untuk mengeliminasi kandidat lintasan yang tidak layak (infeasible) untuk diikuti [22]. Dalam hal ini, lintasan referensi DDWMR antara pose awal dan akhir tertentu umumnya dirancang secara sekuensial menggunakan beberapa titik jalan (waypoint) di antara kedua pose [23]. Secara praktis, lintasan referensi dapat didesain sebagai fungsi polinomial dengan kelengkungan halus (smooth curve) serta memenuhi batasan kondisi tertentu (posisi, kecepatan, dan percepatan kontinu) pada kedua titik jalan yang ditinjau [24].

Di berbagai studi/literatur, perancangan lintasan referensi dan desain kontrol pelacakan DDWMR umumnya dilakukan secara terpisah. Pada makalah ini, pengontrolan pergerakan DDWMR antara dua pose yang berbeda diajukan dalam suatu metode terintegrasi yang secara sekuensial merancang lintasan antara kedua pose untuk kemudian dijadikan sebagai referensi dalam desain pengontrol penjejakan. Lintasan referensi yang dirancang pada tahap pertama dalam metode yang diusulkan adalah kurva polinomial fungsi waktu dengan kelengkungan halus yang menginterpolasikan beberapa titik jalan yang terletak di antara pose awal dan akhir yang diinginkan. Berdasarkan lintasan referensi yang diperoleh tersebut, sinyal kontrol umpan balik berbasis analisis kestabilan Lyapunov kemudian ditentukan untuk menjamin nilai error antara pose aktual robot dan pose lintasan referensi selama pergerakan robot menjadi seminimal mungkin. Hasil simulasi numerik dipaparkan di makalah ini untuk mengilustrasikan keefektifan metode perancangan kontrol penjejakan yang diusulkan.

\section{DESKRIPSI DAN MODEL DDWMR}

\section{A. Deskripsi dan Model Kinematika DDWMR}

Sketsa struktur DDWMR yang ditinjau pada makalah ini ditunjukkan pada Gbr. 1. Robot memiliki dua roda yang masing-masing memiliki diameter $2 r$ m dan terpisah sejauh $2 l$ $\mathrm{m}$ satu sama lain. Roda kiri dan kanan masing-masing memiliki kecepatan sudut $\omega_{L}$ dan $\omega_{R} \mathrm{rad} / \mathrm{s}$. Posisi robot pada suatu subset terbatas $\chi$ di koordinat inersial Kartesian dua dimensi $(X, Y)$ dinyatakan sebagai posisi titik pusat $(x, y)$ dari koordinat lokal robot $\left(x_{\text {robot }}, y_{\text {robot }}\right)$ di bidang $(X, Y)$. Sudut orientasi robot $\varphi$ rad didefinisikan antara vektor kecepatan

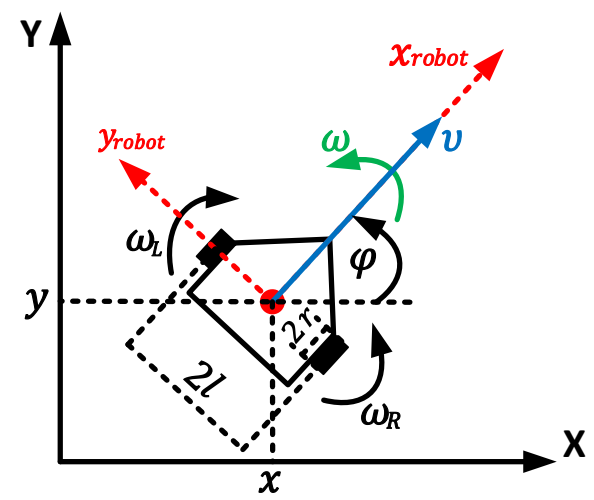

Gbr. 1 Sketsa DDWMR yang ditinjau.

liniernya dengan sumbu $X$ di koordinat inersial. Titik $(x, y, \varphi)$ merupakan pose robot dengan arah vektor kecepatan linier $\mathrm{u} \mathrm{m} / \mathrm{s}$ yang tegak lurus terhadap sumbu putar roda serta kecepatan sudut $\omega \mathrm{rad} / \mathrm{s}$ searah dengan orientasi robot.

Berdasarkan geometri yang ditunjukkan pada Gbr. 1 dan dengan menggunakan analisis aljabar vektor, model kinematika untuk pose DDWMR dapat dituliskan pada (1) [3], [4], [25].

$$
\left[\begin{array}{c}
\dot{x} \\
\dot{y} \\
\dot{\varphi}
\end{array}\right]=\left[\begin{array}{cc}
\cos (\varphi) & 0 \\
\sin (\varphi) & 0 \\
0 & 1
\end{array}\right]\left[\begin{array}{l}
v \\
\omega
\end{array}\right]
$$

dengan kecepatan linier $v$ dan kecepatan sudut $\omega$ merupakan sinyal kontrol masukan yang memenuhi persamaan berikut:

$$
\left[\begin{array}{c}
v \\
\omega
\end{array}\right]=\left[\begin{array}{rr}
\frac{r}{2} & \frac{r}{2} \\
\frac{r}{2 l} & -\frac{r}{2 l}
\end{array}\right]\left[\begin{array}{l}
\omega_{R} \\
\omega_{L}
\end{array}\right] .
$$

Dengan menggabungkan (1) dan (2), model kinematika (1) dapat ditulis ulang sebagai berikut:

$$
\left[\begin{array}{l}
\dot{x} \\
\dot{y} \\
\dot{\varphi}
\end{array}\right]=\left[\begin{array}{cc}
\frac{r}{2} \cos (\varphi) & \frac{r}{2} \cos (\varphi) \\
\frac{r}{2} \sin (\varphi) & \frac{r}{2} \sin (\varphi) \\
\frac{r}{2 l} & -\frac{r}{2 l}
\end{array}\right]\left[\begin{array}{l}
\omega_{R} \\
\omega_{L}
\end{array}\right] .
$$

Persamaan (3) menunjukkan bahwa pose DDWMR dapat dikontrol dengan mengatur kecepatan sudut roda kiri dan kanan.

\section{B. Kontrol Penjejakan Lintasan}

Salah satu tujuan operasional DDWMR adalah terkait pengontrolan geraknya dari pose awal ke pose akhir tertentu. Pada makalah ini, pengontrolan gerak antara kedua pose tersebut dilakukan dengan metode kontrol pelacakan lintasan. Lebih spesifik, DDWMR dikontrol untuk menjejaki lintasan referensi tertentu yang menghubungkan pose awal dan akhir yang diinginkan. Pada makalah ini, lintasan referensi untuk dijejaki dinyatakan sebagai pose referensi $\left(x^{*}, y^{*}, \varphi^{*}\right)$ yang berdasarkan (1) memenuhi model kinematika berikut [4].

$$
\left[\begin{array}{c}
\dot{x}^{*} \\
\dot{y}^{*} \\
\dot{\varphi}^{*}
\end{array}\right]=\left[\begin{array}{cc}
\cos \left(\varphi^{*}\right) & 0 \\
\sin \left(\varphi^{*}\right) & 0 \\
0 & 1
\end{array}\right]\left[\begin{array}{c}
\mathrm{v}^{*} \\
\omega^{*}
\end{array}\right]
$$




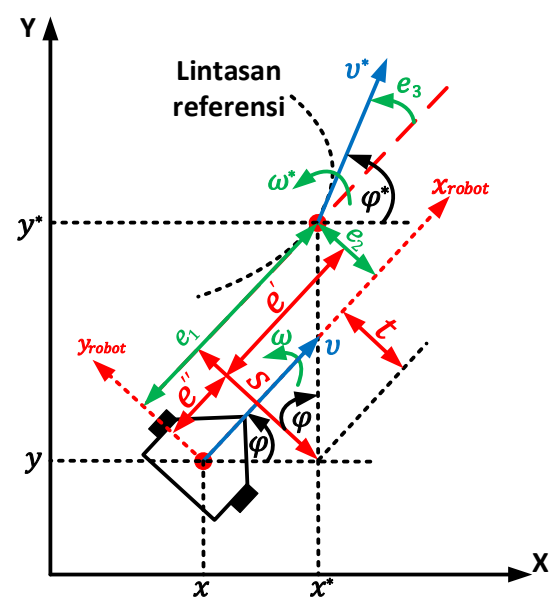

Gbr. 2 Geometri error antara pose aktual DDWMR dan lintasan referensi.

dengan $v^{*}$ dan $\omega^{*}$ merupakan kecepatan linier dan kecepatan sudut referensi. Gbr. 2 secara geometri mengilustrasikan nilai error antara pose aktual DDWMR dan lintasan referensi.

Berdasarkan Gbr. 2, dapat didefinisikan tiga komponen error antara pose lintasan referensi $\left(x^{*}, y^{*}, \varphi^{*}\right)$ dan pose aktual $(x, y, \varphi)$ DDWMR sebagai berikut. Error posisi $e_{1}$ merupakan jarak antara posisi aktual dari DDWMR dan posisi lintasan referensi di sumbu $x_{\text {robot }}$; error posisi $e_{2}$ merupakan jarak antara posisi aktual DDWMR dan posisi lintasan referensi di sumbu $y_{\text {robot }}$; serta error orientasi $e_{3}$ merupakan selisih sudut antara sudut orientasi referensi $\varphi^{*}$ dan sudut orientasi aktual $\varphi$ [15], [26]. Dengan menggunakan analisis geometri di Gbr. 2, nilai setiap komponen error pose tersebut dapat ditentukan sebagai berikut:

$$
\begin{aligned}
& {\left[\begin{array}{l}
e_{1} \\
e_{2} \\
e_{3}
\end{array}\right]=\left[\begin{array}{l}
e_{1}^{\prime \prime}+e_{1}^{\prime} \\
-t+s \\
\varphi^{*}-\varphi
\end{array}\right]} \\
& =\left[\begin{array}{c}
\left(x^{*}-x\right) \cos (\varphi)+\left(y^{*}-y\right) \sin (\varphi) \\
-\left(x^{*}-x\right) \sin (\varphi)+\left(y^{*}-y\right) \cos (\varphi) \\
\varphi^{*}-\varphi
\end{array}\right] \\
& =\left[\begin{array}{ccc}
\cos (\varphi) & \sin (\varphi) & 0 \\
-\sin (\varphi) & \cos (\varphi) & 0 \\
0 & 0 & 1
\end{array}\right]\left[\begin{array}{c}
\left(x^{*}-x\right) \\
\left(y^{*}-y\right) \\
\left(\varphi^{*}-\varphi\right)
\end{array}\right] \text {. }
\end{aligned}
$$

Dengan menghitung turunan terhadap waktu dari model error pada (5) serta menggunakan model kinematika pada (1) dan (4), maka dinamika error penjejakan DDWMR pada lintasan referensi dalam (4) dapat dituliskan sebagai berikut [15]:

$$
\left[\begin{array}{c}
\dot{e_{1}} \\
\dot{e_{2}} \\
\dot{e_{3}}
\end{array}\right]=\frac{d}{d t}\left[\begin{array}{c}
e_{1} \\
e_{2} \\
e_{3}
\end{array}\right]=\left[\begin{array}{cc}
-1 & e_{2} \\
0 & -e_{1} \\
0 & -1
\end{array}\right]\left[\begin{array}{c}
v \\
\omega
\end{array}\right]+\left[\begin{array}{c}
\mathrm{v}^{*} \cos \left(e_{3}\right) \\
\mathrm{u}^{*} \sin \left(e_{3}\right) \\
\omega^{*}
\end{array}\right]
$$

Model dalam (6) menunjukkan bahwa dinamika error penjejakan lintasan referensi bergantung pada nilai kecepatan linier dan kecepatan sudut yang, berdasarkan model (1), juga merupakan sinyal kontrol masukan pada DDWMR. Oleh karena itu, dapat disimpulkan bahwa untuk memastikan bahwa DDWMR mampu menjejaki lintasan referensi tertentu, kecepatan linier dan kecepatan sudut sebagai sinyal kontrol masukan harus dirancang sedemikian rupa sehingga dinamika error penjejakan pada (2) stabil asymptotic. Makalah ini meninjau perancangan sinyal kontrol $v$ dan $\omega$ dengan metode berbasis analisis kestabilan Lyapunov. Secara khusus, dinamika sistem error pada (6) disebut stabil asymptotic jika memenuhi syarat kestabilan Lyapunov pada Definisi 1 [27].

Definisi 1. Tinjau dinamika error penjejakan $\dot{e}=f(e, v, \omega)$ di (6) dengan $e=\left[e_{1}, e_{2}, e_{3}\right]^{T}$. Titik ekuilibrium $e=0$ dari (6) disebut stabil asymptotic dalam pengertian Lyapunov jika terdapat suatu fungsi Lyapunov $V(e)$ kontinu dengan turunan kontinu yang secara simultan memenuhi kondisi berikut:

(i) $V(0)=0$,

(ii) $V(e)>0$ untuk setiap nilai $e \neq 0$,

(iii) $\dot{V}(e)=\left[\frac{\partial V(e)}{\partial e}\right]^{T} \frac{d e}{d t}<0$ untuk setiap $e \neq 0$.

Pada makalah ini, lintasan referensi pada (4) dirancang sebagai suatu kurva fungsi polinomial dengan variabel waktu $t$ dan kelengkungan halus yang menginterpolasikan beberapa titik jalan yang terletak di antara pose awal dan akhir yang diinginkan. Sinyal aksi kontrol $v$ dan $\omega$ untuk penjejakan lintasan referensi tersebut kemudian dirancang berdasarkan kondisi kestabilan Lyapunov pada Definisi 1.

\section{PERANCANGAN KuRVA LinTASAN REFERENSI}

Bagian ini memaparkan metode perancangan lintasan referensi antara pose awal dan akhir dari DDWMR yang diinginkan.

\section{A. Lintasan Referensi Antara Dua Posisi}

Lintasan referensi untuk dijejaki DDWMR ketika bergerak dari titik awal $\left(x_{0}, y_{0}\right)$ dan akhir $\left(x_{f}, y_{f}\right)$ tertentu di koordinat inersial $(X, Y)$ dapat ditentukan sebagai fungsi polinomial parametrik orde $n$ dengan variabel waktu $t$. Dalam hal ini, posisi referensi robot $\left(x^{*}(t), y^{*}(t)\right)$ pada setiap waktu $t$ dapat diasumsikan sebagai fungsi polinomial parametrik berikut:

$$
\begin{aligned}
x^{*}(t) & =\left[\begin{array}{lll}
a_{0} & \ldots & a_{n}
\end{array}\right] p(t), \\
y^{*}(t) & =\left[\begin{array}{lll}
b_{0} & \ldots & b_{n}
\end{array}\right] p(t)
\end{aligned}
$$

dengan $a_{i}$ dan $b_{i}(i=0,1, \cdots, n)$ merupakan konstanta dan $p(t)$ merupakan vektor monomial orde $n$ dengan variabel $t$ :

$$
p(t)=\left[\begin{array}{llll}
1 & t & \cdots & t^{n}
\end{array}\right]^{T} .
$$

Penentuan solusi untuk konstanta parameter $a_{i}$ dan $b_{i}$ pada (7) dilakukan dengan meninjau batasan kondisi waktu $t_{0}$ di titik awal $\left(x_{0}, y_{0}\right)$ dan waktu akhir $t_{f}$ di titik akhir $\left(x_{f}, y_{f}\right)$ yang diinginkan sebagai berikut:

$$
\begin{aligned}
& x^{*}\left(t_{0}\right), y^{*}\left(t_{0}\right),\left.\dot{x}^{*}(t)\right|_{t=t_{0}},\left.\dot{y}^{*}(t)\right|_{t=t_{0}}, \\
&\left.\ddot{x}^{*}(t)\right|_{t=t_{0}},\left.\ddot{y}^{*}(t)\right|_{t=t_{0}}, \\
& x^{*}\left(t_{f}\right), y^{*}\left(t_{f}\right),\left.\dot{x}^{*}(t)\right|_{t=t_{f}},\left.\dot{y}^{*}(t)\right|_{t=t_{f}}, \\
&\left.\ddot{x}^{*}(t)\right|_{t=t_{f}},\left.\ddot{y}^{*}(t)\right|_{t=t_{f}} .
\end{aligned}
$$

Berdasarkan titik awal $\left(x_{0}, y_{0}\right)$ dan akhir $\left(x_{f}, y_{f}\right)$ serta kondisi (9) untuk durasi waktu $t_{0}$ dan $t_{f}$ yang diinginkan, solusi lintasan referensi yang diinginkan ditentukan sebagai berikut: 


$$
\begin{aligned}
& x^{*}(t)=\left[G^{-1}\left(E-H a_{n}\right) a_{n}\right] p(t) \\
& y^{*}(t)=\left[\begin{array}{ll}
G^{-1}\left(F-H b_{n}\right) & b_{n}
\end{array}\right] p(t) .
\end{aligned}
$$

Sebagai ilustrasi, jika $p(t)$ di (8) ditentukan sebagai vektor dengan komponen monomial orde maksimum $n=6$, maka matriks dan vektor $E, F, G$ dan $H$ pada (10) menjadi

$$
\begin{aligned}
& G=\left[\begin{array}{cccccc}
1 & t_{0} & t_{0}^{2} & t_{0}^{3} & t_{0}^{4} & t_{0}^{5} \\
1 & t_{f} & t_{f}^{2} & t_{f}^{3} & t_{f}^{4} & t_{f}^{5} \\
0 & 1 & 2 t_{0} & 3 t_{0}^{2} & 4 t_{0}^{3} & 5 t_{0}^{4} \\
0 & 1 & 2 t_{f} & 3 t_{f}^{2} & 4 t_{f}^{3} & 5 t_{f}^{4} \\
0 & 0 & 2 & 6 t_{0} & 12 t_{0}^{2} & 20 t_{0}^{3} \\
0 & 0 & 2 & 6 t_{f} & 12 t_{f}^{2} & 20 t_{f}^{3}
\end{array}\right]
\end{aligned}
$$

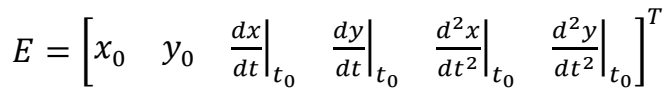

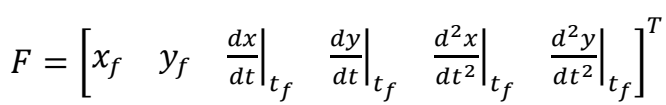

$$
\begin{aligned}
& H=\left[\begin{array}{llllll}
t_{0}^{6} & t_{f}^{6} & 6 t_{0}^{5} & 6 t_{f}^{5} & 30 t_{0}^{4} & 30 t_{f}^{4}
\end{array}\right]^{T} .
\end{aligned}
$$

\section{B. Lintasan Referensi dengan Beberapa Titik Jalan}

Pada subbagian III.A, batasan kondisi berupa kecepatan dan percepatan dalam (9) dapat ditentukan bernilai nol agar dalam pelacakan lintasan referensi DDWMR tidak bergerak pada waktu $t_{0}$ dan $t_{f}$. Jika lintasan referensi yang diinginkan perlu memperhitungkan beberapa titik jalan, maka perlu ditentukan nilai batasan kondisi untuk setiap titik jalan tersebut. Untuk menentukan batasan kondisi tersebut, variasi metode di subbagian III.A dapat digunakan dengan beberapa tambahan syarat/kondisi. Dalam hal ini, ditinjau kondisi ketika titik awal $\left(x_{0}, y_{0}\right)$ dan titik akhir $\left(x_{f}, y_{f}\right)$ yang diinginkan hendak dihubungkan oleh $m \geq 3$ titik jalan $\left(\bar{x}_{i}, \bar{y}_{i}\right)$ untuk $i=1, \cdots, m$, dengan $\left(\bar{x}_{i}, \bar{y}_{i}\right)$ tersebut juga mencakup titik awal dan akhir, sehingga lintasan referensi tersusun atas $d=(m-1)$ segmen lintasan referensi dengan dua titik ujung segmen lintasan referensi ditentukan sebagai titik awal lokal dan titik akhir lokal. Nilai batasan kondisi di titik awal lokal dan titik akhir lokal tersebut ditentukan dengan memanfaatkan $s \leq(m-1)$ segmen, yang dalam hal ini merupakan fungsi polinomial yang menghubungkan $q \leq(m-1)$ buah titik. Dalam hal ini, masing-masing kurva lokal tersebut dapat ditentukan sebagai fungsi polinomial dengan orde $(q-1)$. Lintasan referensi global antara titik awal dan akhir kemudian ditentukan sebagai kurva penyambungan dari $d$ segmen lintasan referensi yang pada setiap titik persambungannya bersifat kontinu dan memiliki kelengkungan halus [23].

Sebagai ilustrasi, ditinjau penentuan lintasan referensi untuk titik jalan $\left(\bar{x}_{i}, \bar{y}_{i}\right)$ dengan $i=1, \cdots, m=6,\left(x_{0}, y_{0}\right)=$ $\left(\bar{x}_{1}, \bar{y}_{1}\right)$, dan $\left(x_{f}, y_{f}\right)=\left(\bar{x}_{6}, \bar{y}_{6}\right)$. Lintasan referensi yang dirancang terdiri atas $d=5$ segmen lintasan referensi. Diasumsikan bahwa desain setiap segmen lintasan referensi dirancang menggunakan $s=3$ segmen kurva lokal, dengan masing-masing kurva lokal tersebut adalah fungsi polinomial variabel waktu $t$ orde $(q-1)=3$ yang menghubungkan $q=$
4 buah titik jalan yang ditinjau. Dalam hal ini, enam titik jalan yang ditinjau merupakan sebuah set dengan tiga segmen kurva lokal, yaitu segmen kurva kiri $(t, \bar{x}, \bar{y})_{L}$, segmen kurva tengah $(t, \bar{x}, \bar{y})_{M}$, dan segmen kurva kanan $(t, \bar{x}, \bar{y})_{R}$ sebagai berikut:

$$
\begin{aligned}
& (t, x, y)_{L}=\left\{t_{1}, \bar{x}_{1}, \bar{y}_{1}, t_{2}, \bar{x}_{2}, \bar{y}_{2}, t_{3}, \bar{x}_{3}, \bar{y}_{3}, t_{4}, \bar{x}_{4}, \bar{y}_{4}\right\} \\
& (t, x, y)_{M}=\left\{t_{2}, \bar{x}_{2}, \bar{y}_{2}, t_{3}, \bar{x}_{3}, \bar{y}_{3}, t_{4}, \bar{x}_{4}, \bar{y}_{4}, t_{5}, \bar{x}_{5}, \bar{y}_{5}\right\} \\
& (t, x, y)_{R}=\left\{t_{3}, \bar{x}_{3}, \bar{y}_{3}, t_{4}, \bar{x}_{4}, \bar{y}_{4}, t_{5}, \bar{x}_{5}, \bar{y}_{5}, t_{6}, \bar{x}_{6}, \bar{y}_{6}\right\} .
\end{aligned}
$$

Masing-masing segmen kurva lokal (12) didefinisikan sebagai fungsi polinomial kubik berikut

$$
\begin{gathered}
x_{\Xi}=a_{0}^{\Xi}+a_{1}^{\Xi} t+a_{2}^{\Xi} t^{2}+a_{3}^{\Xi} t^{3} \\
y_{\Xi}=b_{0}^{\Xi}+b_{1}^{\Xi} t+b_{2}^{\Xi} t^{2}+b_{3}^{\Xi} t^{3}
\end{gathered}
$$

dengan $\Xi=L, M, R$, serta konstanta $a_{0}^{\Xi} \cdots a_{3}^{\Xi}$ dan $b_{0}^{\Xi}, \cdots, b_{3}^{\Xi}$ untuk setiap segmen kurva dapat ditentukan sebagai

$$
A_{\Xi}=T_{\Xi}{ }^{-1} X_{\Xi} \text {, dan } B_{\Xi}=T_{\Xi}^{-1} Y_{\Xi}
$$

Pada (14), $A_{\Xi}$ dan $B_{\Xi}$ merupakan vektor berisi konstanta untuk setiap kurva sebagai berikut:

$$
\begin{aligned}
A_{\Xi} & =\left[\begin{array}{llll}
a_{0}^{\Xi} & a_{1}^{\Xi} & a_{2}^{\Xi} & a_{3}^{\Xi}
\end{array}\right]^{T} \\
B_{\Xi} & =\left[\begin{array}{llll}
b_{0}^{\Xi} & b_{1}^{\Xi} & b_{2}^{\Xi} & b_{3}^{\Xi}
\end{array}\right]
\end{aligned}
$$

sedangkan $X_{\Xi}$ dan $Y_{\Xi}$ merupakan vektor yang mendefinisikan spesifikasi titik jalan pada (13)-(14) dengan bentuk

$$
\begin{aligned}
X_{L} & =\left[\begin{array}{llll}
\bar{x}_{1} & \bar{x}_{2} & \bar{x}_{3} & \bar{x}_{4}
\end{array}\right]^{T}, Y_{L}=\left[\begin{array}{lllll}
\bar{y}_{1} & \bar{y}_{2} & \bar{y}_{3} & \bar{y}_{4}
\end{array}\right]^{T} \quad(16 \mathrm{a}) \\
X_{M} & =\left[\begin{array}{llllll}
\bar{x}_{2} & \bar{x}_{3} & \bar{x}_{4} & \bar{x}_{5}
\end{array}\right]^{T}, Y_{M}=\left[\begin{array}{lllll}
\bar{y}_{2} & \bar{y}_{3} & \bar{y}_{4} & \bar{y}_{5}
\end{array}\right]^{T} \quad(16 \mathrm{~b}) \\
X_{R} & =\left[\begin{array}{llllll}
\bar{x}_{3} & \bar{x}_{4} & \bar{x}_{5} & \bar{x}_{6}
\end{array}\right]^{T}, Y_{R}=\left[\begin{array}{lllll}
\bar{y}_{3} & \bar{y}_{4} & \bar{y}_{5} & \bar{y}_{6}
\end{array}\right]^{T} \quad(16 \mathrm{c})
\end{aligned}
$$

dan $T_{\Xi}$ merupakan matriks variabel waktu $t$ sebagai berikut:

$$
T_{L}=\left[\begin{array}{cccc}
1 & t_{1} & t_{1}^{2} & t_{1}^{3} \\
1 & t_{2} & t_{2}^{2} & t_{2}^{3} \\
1 & t_{3} & t_{3}^{2} & t_{3}^{3} \\
1 & t_{4} & t_{4}^{2} & t_{4}^{3}
\end{array}\right], T_{M}=\left[\begin{array}{cccc}
1 & t_{2} & t_{2}^{2} & t_{2}^{3} \\
1 & t_{3} & t_{3}^{2} & t_{3}^{3} \\
1 & t_{4} & t_{4}^{2} & t_{4}^{3} \\
1 & t_{5} & t_{5}^{2} & t_{5}^{3}
\end{array}\right], T_{R}=\left[\begin{array}{cccc}
1 & t_{3} & t_{3}^{2} & t_{3}^{3} \\
1 & t_{4} & t_{4}^{2} & t_{4}^{3} \\
1 & t_{5} & t_{5}^{2} & t_{5}^{3} \\
1 & t_{6} & t_{6}^{2} & t_{6}^{3}
\end{array}\right]
$$

Gbr. 3 menunjukkan kurva polinomial dari masing-masing segmen kurva lokal kiri, tengah, dan kanan yang akan dikombinasikan untuk membentuk segmen lintasan referensi antara titik $\left(\bar{x}_{3}, \bar{y}_{3}\right)$ dan $\left(\bar{x}_{4}, \bar{y}_{4}\right)$. Dapat dilihat pada gambar tersebut bahwa pertemuan ketiga kurva di titik $\left(\bar{x}_{3}, \bar{y}_{3}\right)$ dan $\left(\bar{x}_{4}, \bar{y}_{4}\right)$ dapat dimanfaatkan untuk memperoleh nilai batasan kondisi yang mengompensasi munculnya potensi sambungan yang tidak kontinu. Dalam hal ini, batasan kondisi pada (9) digunakan untuk memperoleh segmen lintasan referensi berupa kurva interpolasi $\left(x_{\Xi}, y_{\Xi}\right)$ antara titik $\left(\bar{x}_{3}, \bar{y}_{3}\right)$ dan $\left(\bar{x}_{4}, \bar{y}_{4}\right)$. Formulasi kondisi pada (9) untuk dua titik jalan tersebut menjadi

$$
\begin{aligned}
& \left.\dot{x}^{*}(t)\right|_{t_{3}}=\frac{1}{2}\left[\left.\dot{x}_{L}(t)\right|_{t_{3}}+\left.\dot{x}_{M}(t)\right|_{t_{3}}\right] \\
& \left.\dot{y}^{*}(t)\right|_{t_{3}}=\frac{1}{2}\left[\left.\dot{y}_{L}(t)\right|_{t_{3}}+\left.\dot{y}_{M}(t)\right|_{t_{3}}\right] \\
& \left.\ddot{x}^{*}(t)\right|_{t_{3}}=\frac{1}{2}\left[\left.\ddot{x}_{L}(t)\right|_{t_{3}}+\left.\ddot{x}_{M}(t)\right|_{t_{3}}\right] \\
& \left.\ddot{y}^{*}(t)\right|_{t_{3}}=\frac{1}{2}\left[\left.\ddot{y}_{L}(t)\right|_{t_{3}}+\left.\ddot{y}_{M}(t)\right|_{t_{3}}\right]
\end{aligned}
$$


dan

$$
\begin{aligned}
\left.\dot{x}^{*}(t)\right|_{t_{4}} & =\frac{1}{2}\left[\left.\dot{x}_{M}(t)\right|_{t_{4}}+\left.\dot{x}_{R}(t)\right|_{t_{4}}\right] \\
\left.\dot{y}^{*}(t)\right|_{t_{4}} & =\frac{1}{2}\left[\left.\dot{y}_{M}(t)\right|_{t_{4}}+\left.\dot{y}_{R}(t)\right|_{t_{4}}\right] \\
\left.\ddot{x}^{*}(t)\right|_{t_{4}} & =\frac{1}{2}\left[\left.\ddot{x}_{M}(t)\right|_{t_{4}}+\left.\ddot{x}_{R}(t)\right|_{t_{4}}\right] \\
\left.\ddot{y}^{*}(t)\right|_{t_{4}} & =\frac{1}{2}\left[\left.\ddot{y}_{M}(t)\right|_{t_{4}}+\left.\ddot{y}_{R}(t)\right|_{t_{4}}\right] .
\end{aligned}
$$

Perlu diperhatikan bahwa kecepatan linier dan kecepatan sudut referensi dapat ditentukan berdasarkan nilai kecepatan linier referensi $\dot{x}^{*}(t)$ dan $\dot{y}^{*}(t)$ pada sumbu koordinat inersial sebagai berikut:

$$
\begin{gathered}
v^{*}=\sqrt{\left(\dot{x}^{*}(t)\right)^{2}+\left(\dot{y}^{*}(t)\right)^{2}} \\
\omega^{*}=\dot{\varphi}^{*}, \text { dengan } \dot{\varphi}^{*}=\tan ^{-1}\left(\frac{\dot{y}^{*}(t)}{\dot{x}^{*}(t)}\right) .
\end{gathered}
$$

Kurva hasil interpolasi berdasarkan batasan kondisi tersebut ditunjukkan sebagai kurva berwarna merah di Gbr. 3 .

Untuk memperoleh empat segmen lintasan referensi global yang lain, dilakukan proses interpolasi berdasarkan batasan kondisi di setiap titik jalan lainnya. Pada dua titik jalan yang pertama, tiga kurva interpolasi disusun dengan asumsi terdapat dua titik tambahan $\gamma$ dengan susunan seperti pada (12). Dua titik tersebut diletakkan di dekat titik awal pada sebuah garis lurus yang menghubungkan titik $\left(\bar{x}_{1}, \bar{y}_{1}\right),\left(\bar{x}_{2}, \bar{y}_{2}\right)$. Hal yang sama dilakukan untuk menentukan batasan kondisi dua titik jalan terakhir. Ilustrasi penentuan titik tambahan $\gamma_{g}$ dengan $g=1, \cdots, 4$ ditunjukkan pada Gbr. 4 .

Berdasarkan penentuan tersebut, susunan segmen untuk menentukan batasan kondisi untuk dua titik jalan pertama dan dua titik jalan terakhir pada Gbr. 3 tersusun sebagai berikut:

- Batasan kondisi untuk titik $\left(\bar{x}_{1}, \bar{y}_{1}\right)$ dan $\left(\bar{x}_{2}, \bar{y}_{2}\right)$ diperoleh dengan tambahan titik $\gamma_{g}$ untuk $g=\{1,2\}$, sehingga set terdiri atas $\left(t_{\gamma}, \bar{x}_{\gamma}, \bar{y}_{\gamma}\right),\left(t_{1}, \bar{x}_{1}, \bar{y}_{1}\right),\left(t_{2}, \bar{x}_{2}, \bar{y}_{2}\right),\left(t_{3}, \bar{x}_{3}, \bar{y}_{3}\right)$, dan $\left(t_{4}, \bar{x}_{4}, \bar{y}_{4}\right)$.

- Batasan kondisi untuk titik $\left(\bar{x}_{5}, \bar{y}_{5}\right)$ dan $\left(\bar{x}_{6}, \bar{y}_{6}\right)$ diperoleh dengan tambahan titik $\gamma_{g}$ untuk $g=\{3,4\}$, sehingga set terdiri atas $\left(t_{3}, \bar{x}_{3}, \bar{y}_{3}\right),\left(t_{4}, \bar{x}_{4}, \bar{y}_{4}\right),\left(t_{5}, \bar{x}_{5}, \bar{y}_{5}\right),\left(t_{6}, \bar{x}_{6}, \bar{y}_{6}\right)$, $\left(t_{\gamma}, \bar{x}_{\gamma}, \bar{y}_{\gamma}\right)$

Dapat divalidasi berdasarkan pemenuhan batasan kondisi pada (9) dalam bentuk (18)-(19) untuk setiap titik jalan bahwa kurva lintasan referensi global yang diperoleh selalu kontinu di setiap titik jalan yang ditentukan.

Komentar 1. Perlu diperhatikan bahwa model polinomial parametrik pada (7)-(8) yang menghubungkan titik awal dan titik akhir tertentu dapat langsung ditentukan (misalnya dengan interpolasi atau curve fitting) tanpa memperhitungkan batasan turunan fungsi di (9). Peninjauan batasan kondisi pada (9) dalam penentuan solusi dalam (10) dilakukan untuk memastikan bahwa nilai referensi kecepatan awal dan akhir dari pergerakan robot realistis secara praktis. Sebagaimana diilustrasikan pada contoh simulasi di bagian $\mathrm{V}$, penentuan kurva lintasan referensi pada (7) tanpa memperhitungkan

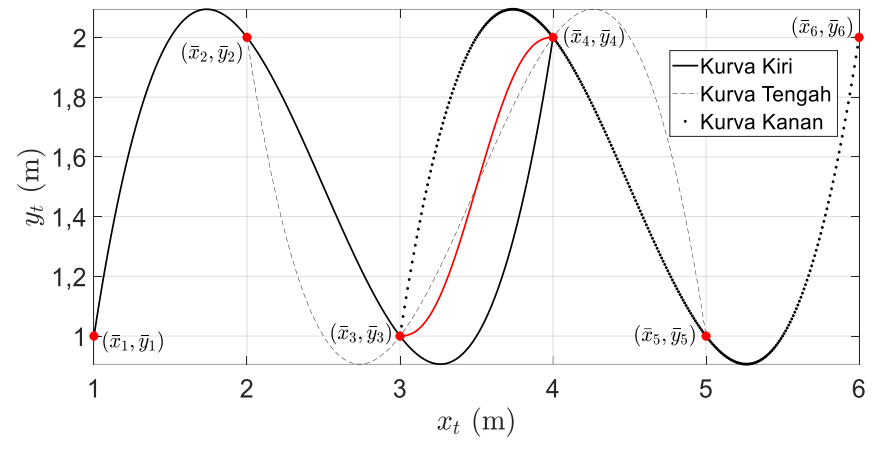

Gbr. 3 Visualisasi penentuan kurva lintasan referensi.
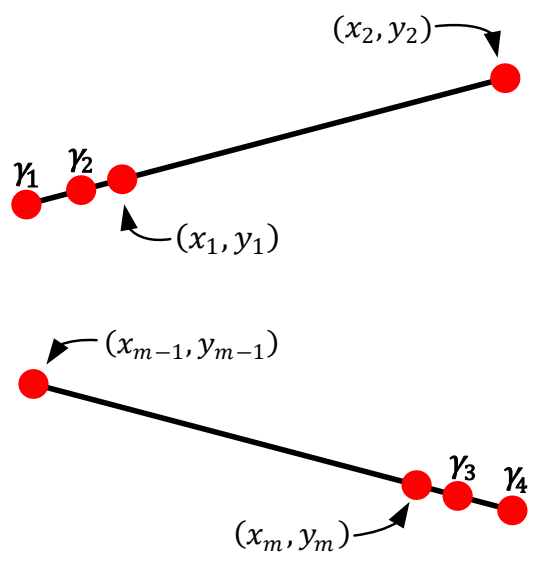

Gbr. 4 Ilustrasi penentuan titik tambahan $\gamma_{g}$.

batasan kondisi pada (9) akan menghasilkan referensi kecepatan awal dan akhir DDWMR yang tidak realistis secara praktis.

\section{Perancangan Kontrol PenJeJakan Berbasis ANALISIS KESTABILAN LYAPUNOV}

Berdasarkan model kinematika pada (3), error penjejakan pada (6), dan lintasan referensi dalam (7), metode kontrol penjejakan suatu lintasan referensi berdasarkan kriteria kestabilan Lyapunov (lihat juga Definisi 1) dapat didesain. Gbr. 5 menunjukkan diagram blok sistem umpan-balik putaran tertutup (closed loop feedback system) DDWMR yang ditinjau pada makalah ini, dengan sinyal kontrol penjejakan merupakan fungsi dari dinamika error penjejakan pada (4). Dalam hal ini, sinyal kontrol dapat dirancang secara konstruktif dengan mengasumsikan terlebih dahulu keberadaan suatu kandidat fungsi Lyapunov terparameterisasi $V(e)$ untuk sistem umpan-balik putaran tertutup DDWMR tersebut. Dengan mengevaluasi kondisi pada parameter fungsi $V(e)$ dengan $e=\left[\begin{array}{lll}e_{1} & e_{2} & e_{3}\end{array}\right]^{T}$ yang menjamin kestabilan dinamika error penjejakan pada (4), sinyal kontrol penjejakan untuk dinamika putaran tertutup DDWMR dapat ditentukan. Sistematika perancangan sinyal kontrol tersebut dijelaskan secara detail sebagai berikut.

Ditinjau kandidat fungsi Lyapunov terparameterisasi untuk dinamika error penjejakan pada (6) berikut:

$$
V\left(e_{1}, e_{2}, e_{3}\right)=\frac{1}{2}\left(e_{1}^{2}+e_{2}^{2}\right)+\frac{1}{K_{2}}\left[1-\cos \left(e_{3}\right)\right]
$$




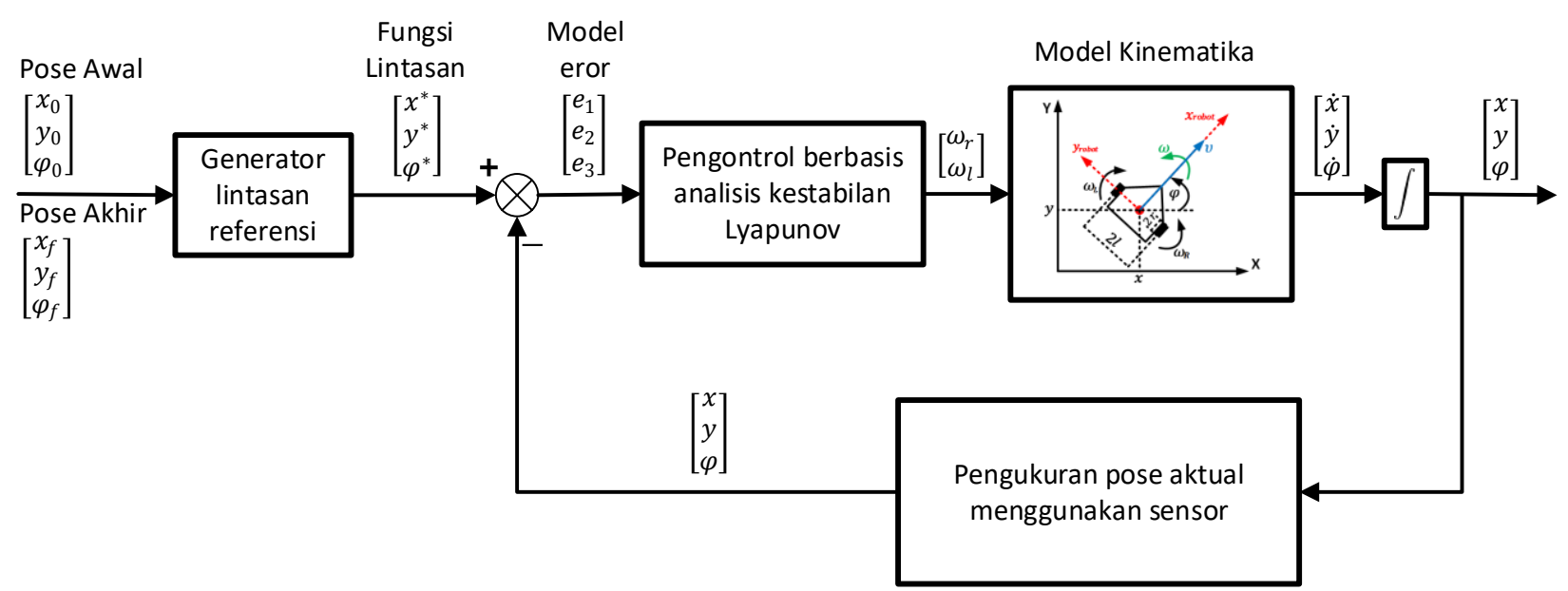

Gbr. 5 Diagram blok sistem kontrol penjejakan putaran tertutup.

dengan $K_{2}>0$ merupakan parameter konstanta. Perlu diperhatikan bahwa untuk bidang kerja berbentuk subset terbatas $\chi$ pada koordinat Kartesian dua dimensi, fungsi $V(e)$ dan turunannya selalu kontinu. Untuk menentukan sinyal kontrol DDWMR yang memastikan dinamika error penjejakan pada (6) stabil asymptotic, fungsi Lyapunov $V(e)$ di (21) dievaluasi berdasarkan kondisi (i)-(iii) pada Definisi 1.

- Untuk nilai $e=0$, diperoleh bahwa $V(e)=0$, sehingga disimpulkan bahwa bahwa $V(e)$ memenuhi kondisi (i).

- Untuk semua nilai $\left(e_{1}, e_{2}, e_{3}\right) \neq 0$, maka $e_{1}^{2}+e_{2}^{2} \neq 0$ dan $\left[1-\cos \left(e_{3}\right)\right] / K_{2} \neq 0$, sehingga $V(e) \neq 0$ untuk $e \neq 0$ dan disimpulkan $V(e)$ memenuhi kondisi (ii).

- Untuk setiap $e \neq 0$, turunan $V(e)$ terhadap waktu adalah:

$$
\dot{V}(e)=e_{1} \dot{e}_{1}+e_{2} \dot{e_{2}}-\frac{1}{K_{2}^{2}}\left(-\sin \left(e_{3}\right) \dot{e_{3}} K_{2}\right) \text {. }
$$

Dengan mensubstitusikan (6) ke (22), diperoleh

$$
\begin{aligned}
\dot{V}(e) & =e_{1}\left(v^{*} \cos \left(e_{3}\right)-v\right) \\
& +\sin \left(e_{3}\right)\left[\frac{1}{K_{2}}\left(\omega^{*}-\omega\right)+v^{*} e_{2}\right] .
\end{aligned}
$$

Untuk memenuhi syarat $\dot{V}(e) \leq 0$ pada kondisi (iii), ditinjau parameterisasi turunan $V(e)$ terhadap waktu berikut:

$$
\dot{V}(e)=-\left(K_{1} e_{1}^{2}+K_{3} \sin ^{2}\left(e_{3}\right)\right)
$$

dengan $K_{1}, K_{3}>0$ merupakan parameter konstanta untuk turunan $\dot{V}(e)$. Dengan membandingkan nilai turunan pada (23) dan asumsi bentuk parameterisasi pada (24), dapat diperoleh dua persamaan sebagai berikut:

$$
\begin{aligned}
-K_{1} e_{1}^{2} & =e_{1}\left(v^{*} \cos \left(e_{3}\right)-v\right) \\
-K_{3} \sin ^{2}\left(e_{3}\right) & =\sin \left(e_{3}\right)\left(\frac{\omega^{*}}{K_{2}}+v^{*} e_{2}-\frac{\omega}{K_{2}}\right)
\end{aligned}
$$

sehingga sinyal kontrol berupa kecepatan linier $v$ berikut dapat diperoleh dari (25a):

$$
v=v^{*} \cos \left(e_{3}\right)+K_{1} e_{1}
$$

serta sinyal kontrol berupa kecepatan sudut $\omega$ berikut dapat diperoleh dari (25b):
TABEL I

KOORDINAT TITIK JALAN REFERENSI

\begin{tabular}{|c|c|c|c|}
\hline Titik Jalan ke-i & $\overline{\boldsymbol{x}}_{\boldsymbol{i}}$ & $\overline{\boldsymbol{y}}_{\boldsymbol{i}}$ & $\boldsymbol{t}_{\boldsymbol{i}}$ \\
\hline$i=1$ & 0 & 0 & 0,1 \\
\hline$i=2$ & 2 & 2 & 5 \\
\hline$i=3$ & 3 & 1 & 10 \\
\hline$i=4$ & 4 & 2 & 15 \\
\hline$i=5$ & 5 & 1 & 20 \\
\hline
\end{tabular}

$$
\omega=\omega^{*}+K_{2} v^{*} e_{2}+K_{2} K_{3} \sin \left(e_{3}\right) .
$$

Berdasarkan relasi antara kecepatan $(v, \omega)$ DDWMR dan kecepatan sudut $\left(\omega_{R}, \omega_{L}\right)$ dari roda kiri dan kanannya pada (2), sinyal kontrol untuk penjejakan lintasan dalam bentuk kecepatan putar roda kiri dan kanan adalah:

$$
\begin{aligned}
& \omega_{R}=\frac{1}{r}\left[v^{*}\left(\cos \left(e_{3}\right)+l K_{2} e_{2}\right)+\beta\right] \\
& \omega_{L}=\frac{1}{r}\left[v^{*}\left(\cos \left(e_{3}\right)-l K_{2} e_{2}\right)-\alpha\right]
\end{aligned}
$$

dengan $\alpha=l\left(\omega^{*}+K_{2} K_{3} \sin \left(e_{3}\right)\right)-K_{1} e_{1}$, dan $\beta=K_{1} e_{1}+$ $l\left(\omega^{*}+K_{2} K_{3} \sin \left(e_{3}\right)\right)$.

\section{SimULASI DAN ANALISIS}

Bagian ini menjelaskan skenario simulasi yang ditinjau serta hasil yang diperoleh ketika memvalidasi metode perancangan lintasan referensi dan desain pengontrol pelacakan lintasan sebagaimana dipaparkan di bagian III dan IV. Skenario yang ditinjau mengasumsikan $i=5$ titik jalan sebagai referensi pergerakan robot, seperti ditunjukkan pada Tabel I, dengan kecepatan awal dan kecepatan akhir bernilai nol. Simulasi numerik dilakukan pada MATLAB dengan asumsi nilai parameter $r=0.075 \mathrm{~m}$ dan $l=0.19 \mathrm{~m}$ pada model robot di Gbr. 1.

\section{A. Perancangan Kurva Lintasan Referensi}

1) Solusi tanpa Batasan Kondisi: Untuk lima titik jalan yang ditentukan, perancangan lintasan referensi tanpa batasan berdasarkan kondisi pada (9) dilakukan menggunakan fungsi polinomial orde $(i-1)=4$. Kurva lintasan referensi dan sudut orientasi referensi yang menghubungkan semua titik 


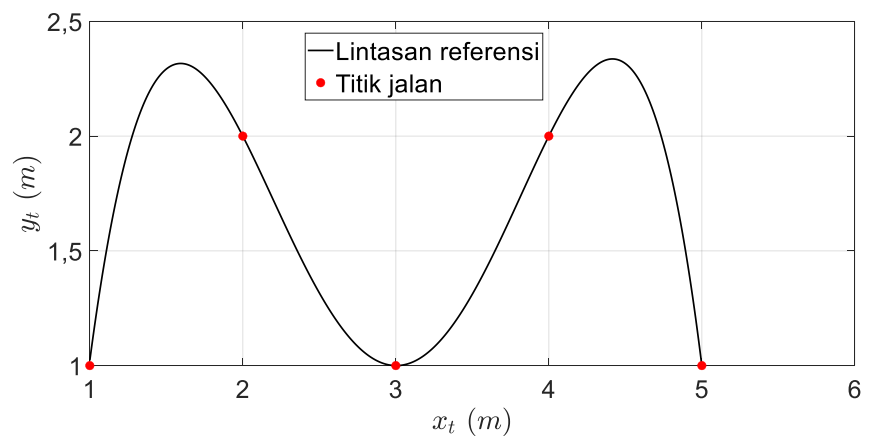

Gbr. 6 Lintasan/posisi referensi tanpa batasan kondisi.

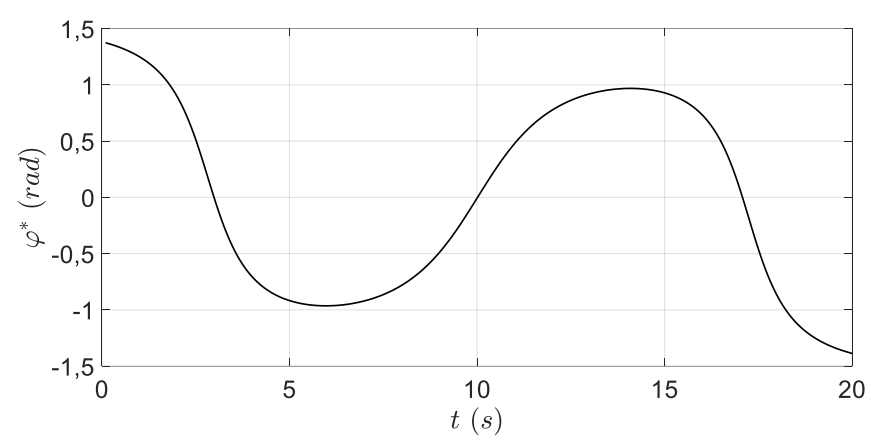

Gbr. 7 Profil sudut orientasi referensi tanpa batasan kondisi.

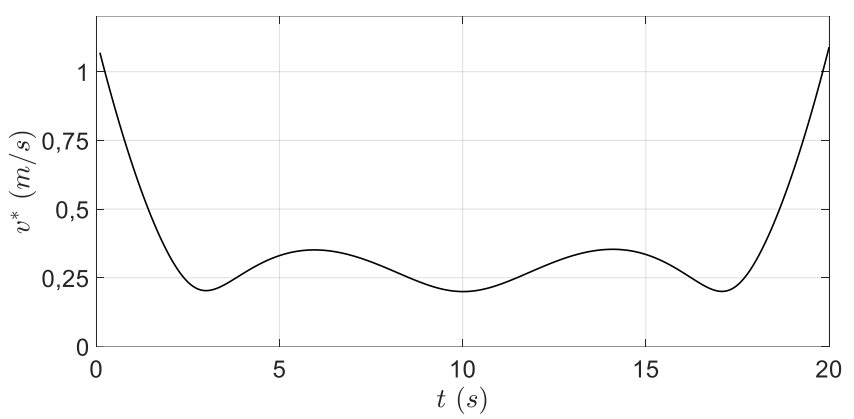

Gbr. 8 Profil kecepatan linier referensi tanpa batasan kondisi.

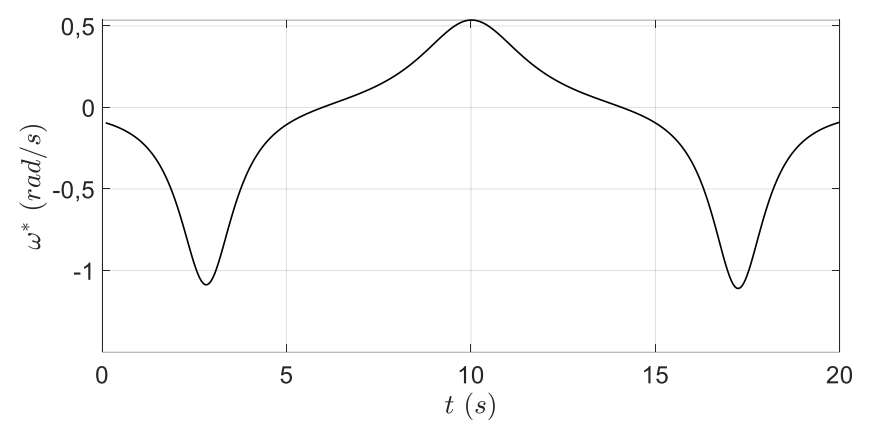

Gbr. 9 Profil kecepatan sudut referensi tanpa batasan kondisi.

jalan ditunjukkan pada Gbr. 6 dan Gbr. 7. Profil kecepatan linier dan kecepatan sudut untuk kurva lintasan referensi tersebut masing-masing ditunjukkan pada Gbr. 8 dan Gbr. 9.

Dapat dilihat pada Gbr. 6 dan Gbr. 7 bahwa kurva lintasan referensi yang dihasilkan selalu kontinu pada titik jalan yang ditentukan. Namun, profil kecepatan referensi pada Gbr. 8 dan Gbr. 9 menunjukkan bahwa referensi kecepatan linier dan kecepatan sudut tidak bernilai nol sebagaimana diinginkan.
TABEL II

KOORDINAT TITIK TAMBAHAN

\begin{tabular}{|c|c|c|c|}
\hline Titik Tambahan ke- $\boldsymbol{g}$ & $\overline{\boldsymbol{x}}_{\boldsymbol{g}}$ & $\overline{\boldsymbol{y}}_{\boldsymbol{g}}$ & $\boldsymbol{t}_{\boldsymbol{g}}$ \\
\hline$g=1$ & 0,9999998 & 0,9999998 & 0 \\
\hline$g=2$ & 0,9999999 & 0,9999999 & 0.05 \\
\hline$g=3$ & 5,0000001 & 0,9999999 & 20,05 \\
\hline$g=4$ & 5,0000002 & 0,9999998 & 20,1 \\
\hline
\end{tabular}

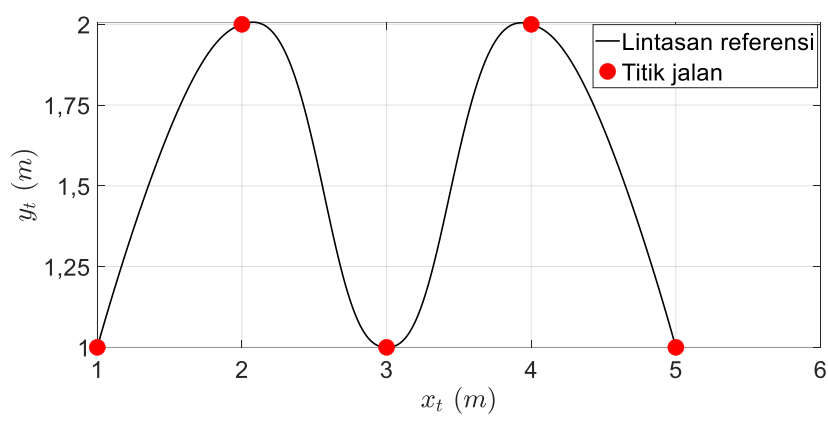

Gbr. 10 Lintasan/posisi referensi tanpa batasan kondisi.

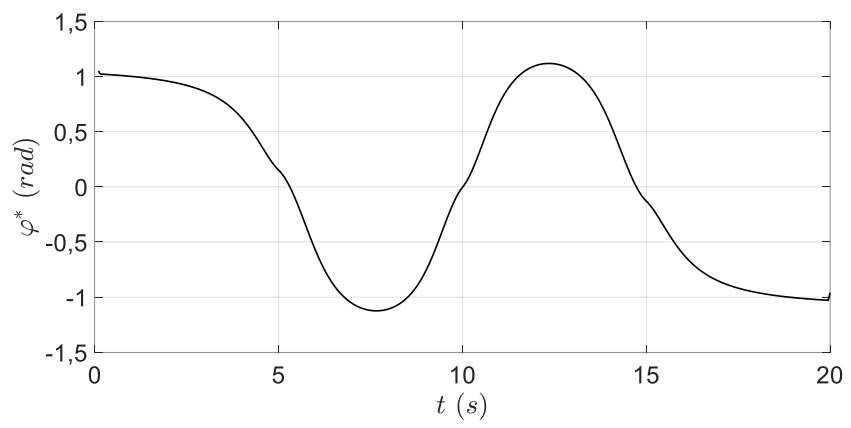

Gbr. 11 Profil sudut orientasi referensi dengan batasan kondisi.

2) Solusi dengan Batasan Kondisi: Dengan meninjau skenario simulasi di bagian V.A.1 dan titik tambahan $\gamma_{g}$ di Tabel II, perancangan lintasan referensi dilakukan dengan batasan kondisi pada (9). Kurva lintasan dan sudut orientasi referensi pada Gbr. 10 dan Gbr. 11 untuk kasus ini menunjukkan bahwa lintasan referensi yang dihasilkan selalu kontinu di titik jalan yang ditentukan. Lebih jauh, referensi profil kecepatan linier dan sudut di Gbr. 12 dan Gbr. 13 menunjukkan kecepatan awal dan akhir DDWMR bernilai nol sebagaimana diinginkan. Dapat disimpulkan bahwa kondisi pada (9) menghasilkan lintasan referensi yang lebih realistis untuk implementasi praktis.

\section{B. Perancangan Pengontrol Penjejak Lintasan Referensi}

Berdasarkan kurva lintasan referensi yang diperoleh pada bagian V.A, simulasi dilanjutkan dengan evaluasi keandalan sinyal kontrol pada (28) dalam menjejaki lintasan referensi yang diperoleh. Simulasi dilakukan dengan menggunakan parameter $K_{1}=5, K_{2}=6$, dan $K_{3}=5$ pada formulasi sinyal kontrol dalam (28).

1) Simulasi Putaran Tertutup tanpa Batasan Kondisi: Untuk kurva lintasan referensi di Gbr. 6, perbandingan kurva posisi aktual dan posisi referensi hasil simulasi putaran tertutup ditunjukkan pada Gbr. 14, sedangkan perbandingan orientasi aktual dan orientasi referensi ditunjukkan di Gbr. 15. 


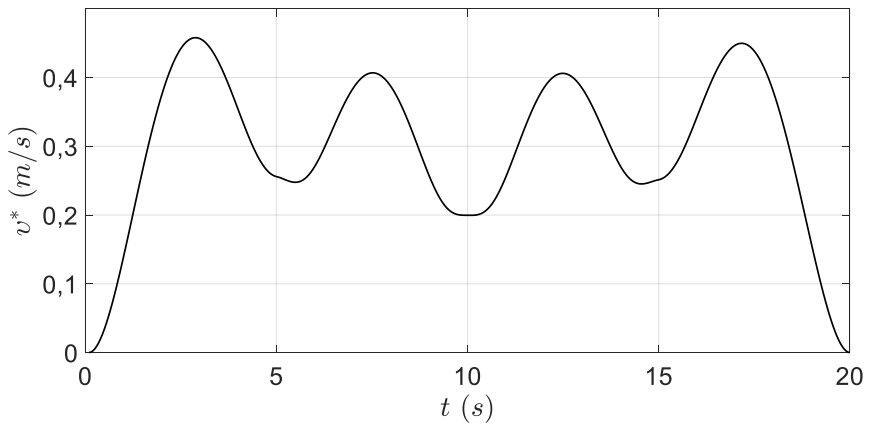

Gbr. 12 Profil kecepatan linier referensi dengan batasan kondisi.

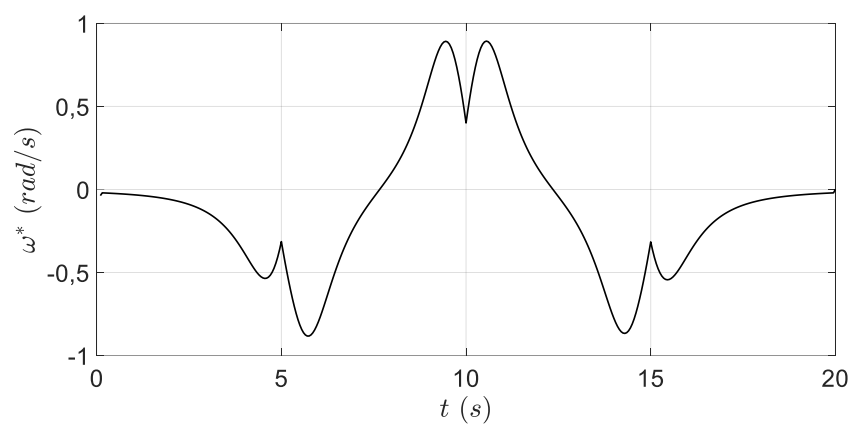

Gbr. 13 Profil kecepatan sudut referensi dengan batasan kondisi.

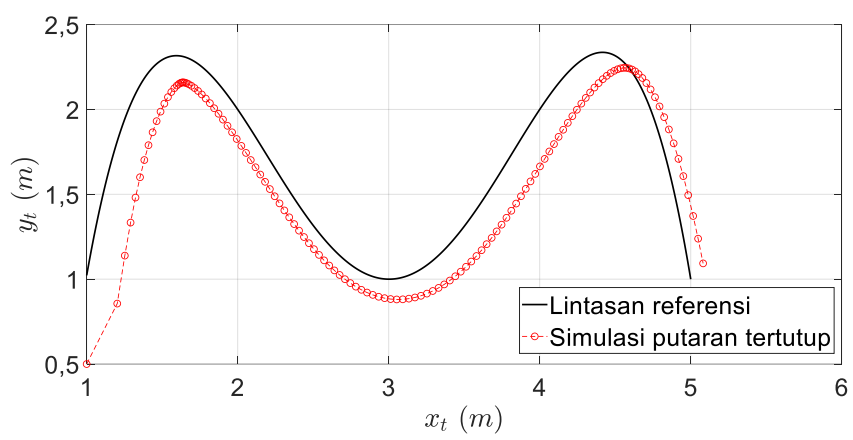

Gbr. 14 Perbandingan posisi referensi dan aktual pada simulasi putaran tertutup tanpa batasan kondisi.

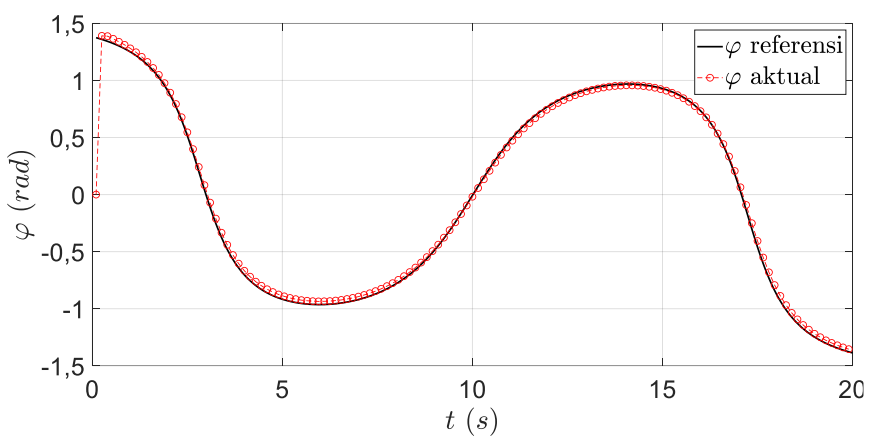

Gbr. 15 Perbandingan orientasi referensi dan aktual pada simulasi putaran tertutup tanpa batasan kondisi.

Lebih jauh, perbandingan sinyal kontrol kecepatan linier dan kecepatan sudut dalam hal ini ditunjukkan di Gbr. 16 dan Gbr. 17. Dapat dilihat pada Gbr. 14 bahwa posisi aktual robot tidak mampu menjejaki posisi referensi secara sempurna dari awal hingga akhir simulasi. Selain itu, kecepatan awal aktual robot yang tidak sama dengan nol membuat sinyal kontrol ini kurang realistis untuk diimplementasikan secara praktis.

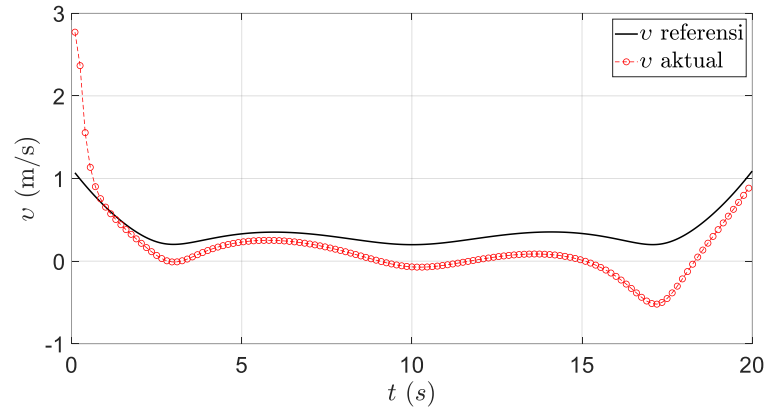

Gbr. 16 Perbandingan kecepatan linier referensi dan aktual pada simulasi putaran tertutup tanpa batasan kondisi.

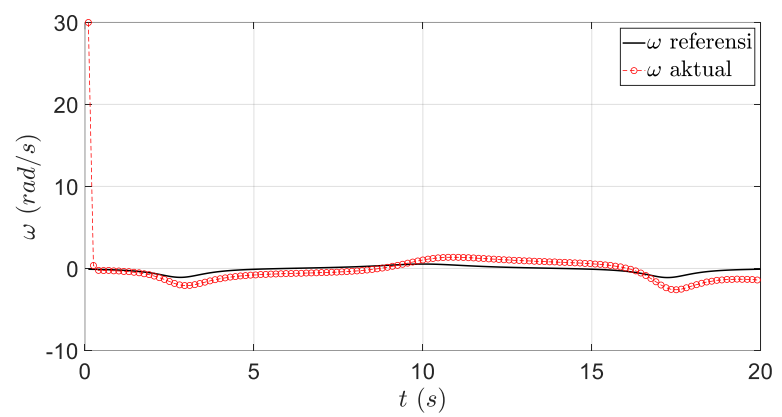

Gbr. 17 Perbandingan kecepatan sudut referensi dan aktual pada simulasi putaran tertutup tanpa batasan kondisi.

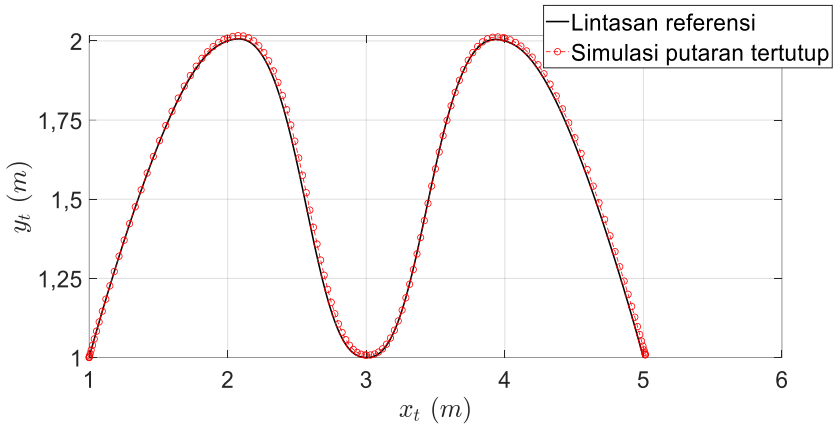

Gbr. 18 Perbandingan posisi referensi dan aktual pada simulasi putaran tertutup dengan batasan kondisi.

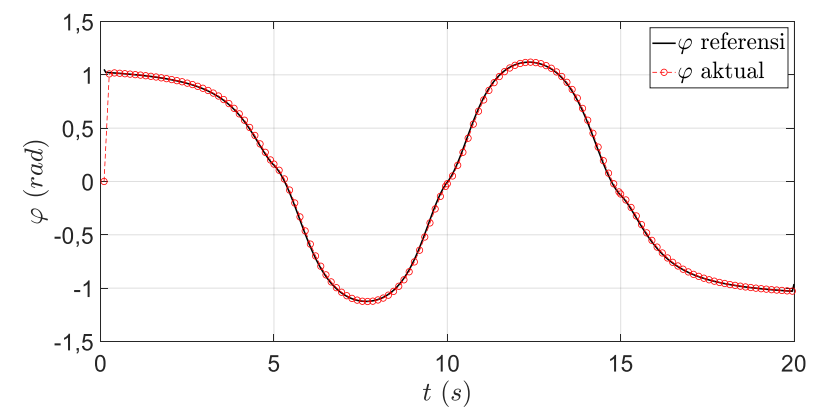

Gbr. 19 Perbandingan orientasi referensi dan aktual pada simulasi putaran tertutup dengan batasan kondisi.

2) Simulasi Putaran Tertutup dengan Batasan Kondisi: Untuk kurva lintasan referensi pada Gbr. 10, perbandingan kurva posisi aktual dan posisi referensi hasil simulasi putaran tertutup ditunjukkan pada Gbr. 18, sedangkan perbandingan orientasi aktual dan orientasi referensi ditunjukkan pada Gbr. 19. Sementara itu, perbandingan sinyal kontrol antara hasil 


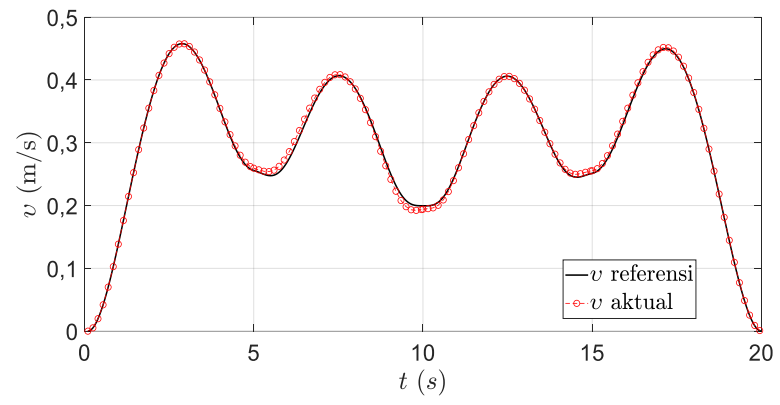

Gbr. 20 Perbandingan kecepatan linier referensi dan aktual pada simulasi putaran tertutup dengan batasan kondisi.

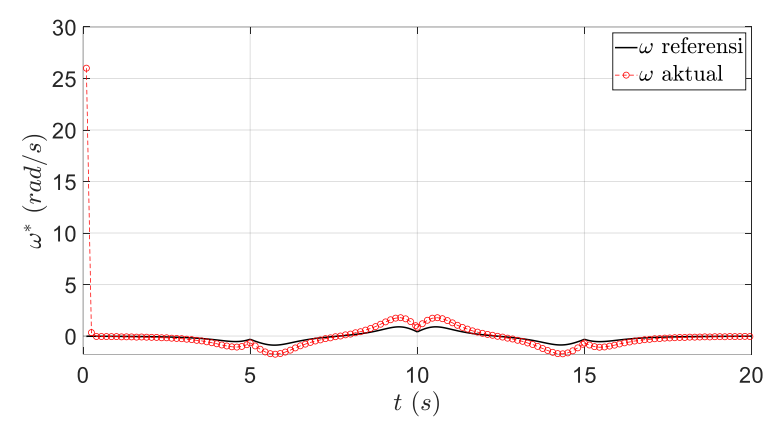

Gbr. 21 Perbandingan kecepatan sudut referensi dan aktual pada simulasi putaran tertutup dengan batasan kondisi.

simulasi dan referensi berupa kecepatan linier dan kecepatan sudut untuk kasus ini masing-masing ditunjukkan pada Gbr. 20 dan Gbr. 21.

Gbr. 18 menunjukkan bahwa posisi aktual robot menjejaki posisi referensi dengan baik dari awal hingga akhir simulasi. Selain itu, kecepatan aktual robot di titik awal dan akhir yang bernilai nol mengindikasikan sinyal kontrol ini lebih realistis untuk diimplementasikan secara praktis. Hal ini menunjukkan efektivitas metode desain lintasan dan kontrol yang diusulkan.

\section{KESIMPULAN}

Makalah ini telah memaparkan suatu metode pengontrolan pergerakan DDWMR dalam menjejaki suatu lintasan referensi yang menghubungkan pose awal dan pose akhir tertentu. Metode yang diusulkan secara sekuensial merancang lintasan antara kedua pose untuk kemudian dijadikan sebagai referensi dalam desain pengontrol penjejakan. Lintasan referensi yang dirancang merupakan kurva polinomial fungsi waktu dengan kelengkungan halus yang menginterpolasikan beberapa titik jalan yang terletak di antara pose awal dan pose akhir yang diinginkan. Berdasarkan lintasan referensi yang diperoleh, sinyal kontrol berbasis analisis kestabilan Lyapunov kemudian ditentukan secara konstruktif untuk meminimalkan nilai error antara pose aktual robot dan pose lintasan referensi. Hasil simulasi numerik menunjukkan bahwa metode kontrol yang diusulkan efektif dalam penjejakan DDWMR yang diusulkan.

\section{REFERENSI}

[1] S.G. Tzafestas, Introduction to Mobile Robot Control, London, England Elsevier, 2013

[2] G. Klancar, A. Zdesar, dan S. Blazic, Wheeled Mobile Robotics: From Fundamentals towards Autonomous Systems, London, England: Butterworth-Heinemann, 2017.
[3] J.L. Avendaño-Juárez, V.M. Hernández-Guzmán, dan R. Silva-Ortigoza, "Velocity and Current Inner Loops in a Wheeled Mobile Robot," Adv. Robot., Vol. 24, No. 8-9, hal. 1385-1404, 2010.

[4] J.R. García-Sánchez, S. Tavera-Mosqueda, R. Silva-Ortigoza, V.M Hernández-Guzmán, J. Sandoval-Gutiérrez, M. Marcelino-Aranda, H. Taud, dan M. Marciano-Melchor, "Robust Switched Tracking Control for Wheeled Mobile Robots Considering the Actuators and Drivers," Sensors, Vol. 18, No. 12, hal. 1-21, 2018.

[5] C. Liu, J. Gao, dan D. Xu, "Lyapunov-based Model Predictive Control for Tracking of Nonholonomic Mobile Robots Under Input Constraints," Int. J. Control Autom. Syst., Vol. 15, hal. 2313-2319, 2017.

[6] K.R. Simba, N. Uchiyama, dan S. Sano, "Real-Time Smooth Trajectory Generation for Nonholonomic Mobile Robots using Bézier Curves,' Robot. Com.-Int. Manuf., Vol. 41, hal. 31-42, 2016.

[7] C.M. Sanchez, J.R.G. Sanchez, C.Y.S. Cervantes, R.S. Ortigoza, V.M.H. Guzman, J.N.A. Juarez, dan M.M. Aranda, "Trajectory Generation for Wheeled Mobile Robots via Bézier Polynomials," IEEE Lat. Am. Trans., Vol. 14, No. 11, hal. 4482-4490, 2016.

[8] J. Mu, X.-G. Yan, S.K. Spurgeon, dan Z. Mao, "Nonlinear Sliding Mode Control of a Two-Wheeled Mobile Robot System," Int. J. Model. Identif. Control., Vol. 27, No. 2, hal. 75-83, 2017.

[9] J.R. García-Sánchez, R. Silva-Ortigoza, S. Tavera-Mosqueda, C. Márquez-Sánchez, V.M. Hernández-Guzmán, M. Antonio-Cruz, G. Silva-Ortigoza, dan H. Taud, "Tracking Control for Mobile Robots Considering the Dynamics of All Their Subsystems: Experimental Implementation," Complexity, Vol. 2017, hal. 1-18, 2017.

[10] R.S. Ortigoza, J.R.G. Sanchez, V.M.H. Guzman, C.M. Sanchez, dan M.M. Aranda, "Trajectory Tracking Control for a Differential Drive Wheeled Mobile Robot Considering the Dynamics Related to Actuators and Power Stage," IEEE Lat. Am. Trans., Vol. 14, No. 2, hal. 657-664, 2016.

[11] D. Huang, J. Zhai, W. Ai, dan S. Fei, "Disturbance Observer-based Robust Control for Trajectory Tracking of Wheeled Mobile Robots," Neurocomputing, Vol. 198, hal. 74-79, 2016.

[12] S. Roy dan I.N. Kar, "Adaptive Robust Tracking Control of a Class of Nonlinear Systems with Input Delay,” Nonlinear Dyn., Vol. 85, No. 2, hal. 1127-1139, 2016.

[13] Y. Kim dan B.K. Kim, "Time-Optimal Trajectory Planning Based on Dynamics for Differential-Wheeled Mobile Robots with a Geometric Corridor," IEEE Trans. Ind. Electron., Vol. 64, No. 7, hal. 5502-5512, 2017.

[14] C.-L. Hwang dan W.-L. Fang, "Global Fuzzy Adaptive Hierarchical Path Tracking Control of a Mobile Robot with Experimental Validation," IEEE Trans. Fuzzy Syst., Vol. 24, No. 3, hal. 724-740, 2015.

[15] T. Fukao, H. Nakagawa, dan N. Adachi, "Adaptive Tracking Control of a Nonholonomic Mobile Robot," IEEE Trans. Robot Autom., Vol. 16 , No. 5, hal. 609-615, 2000.

[16] Z. Peng, G. Wen, S. Yang, dan A. Rahmani, "Distributed Consensusbased Formation Control for Nonholonomic Wheeled Mobile Robots Using Adaptive Neural Network," Nonlinear Dyn., Vol. 86, No.1, hal. 605-622, 2016.

[17] M. Abdelwahab, V. Parque, A.M.R. Fath Elbab, A.A. Abouelsoud, dan S. Sugano, "Trajectory Tracking of Wheeled Mobile Robots using ZNumber Based Fuzzy Logic," IEEE Access, Vol. 8, hal. 18426-18441, 2020.

[18] H.M. Wu dan M. Karkoub, "Hierarchical Fuzzy Sliding-Mode Adaptive Control for the Trajectory Tracking of Differential-Driven Mobile Robots," Int. J. Fuzzy Syst., Vol. 21, No. 1, hal. 33-49, 2019.

[19] T.Q. Khai dan Y.J. Ryoo, "Design of Adaptive Kinematic Controller Using Radial Basis Function Neural Network for Trajectory Tracking Control of Differential-Drive Mobile Robot," Int J. Fuzzy Log. Intell. Syst., Vol. 19, No. 4, hal. 349-359, 2019.

[20] T.Q. Khai, Y.J. Ryoo, W.R. Gill, dan D.Y. Im, "Design of Kinematic Controller Based on Parameter Tuning by Fuzzy Inference System for Trajectory Tracking of Differential-Drive Mobile Robot," Int. J. Fuzzy Syst., Vol. 22, No. 6, hal. 1972-1978, 2020.

[21] X. Wu, P. Jin, T. Zou, Z. Qi, H. Xiao, dan P. Lou, "Backstepping Trajectory Tracking Based on Fuzzy Sliding Mode Control for 
Differential Mobile Robots," J. Intell. Robot Syst. Theory Appl., Vol. 96, No. 1, hal. 109-121, 2019.

[22] Y. Guo, Z. Qu, dan J. Wang, "A New Performance-based Motion Planner for Nonholonomic Mobile Robots," Proc. $3^{\text {rd }}$ PerMIS, 2003, hal. 1-8.

[23] Y. Guo, Y. Long, dan W. Sheng, "Global Trajectory Generation for Nonholonomic Robots in Dynamic Environments," Proc. IEEE ICRA, 2007, hal. 1324-1329.

[24] J.L. Junkins, J.R. Jancaitis, dan G.W. Miller, "Smooth Irregular Curves," Photogramm. Eng. Rem. S., Vol. 38, No. 6, hal. 565-573, 1972.
[25] Y. Kanayama, Y. Kimura, F. Miyazaki, dan T. Noguchi, "A Stable Tracking Control Method for an Autonomous Mobile Robot," Proc. IEEE ICRA, 1990, hal. 384-389.

[26] R. Fierro dan F.L. Lewis, "Control of a Nonholonomic Mobile Robot: Backstepping Kinematics into Dynamics," Proc. 34th IEEE CDC, 1995 , hal. 3805-3810.

[27] S.G. Tzafestas, "Mobile Robot Control I: The Lyapunov-Based Method," dalam Introduction to Mobile Robot Control, Oxford, UK: Elsevier, 2014, hal. 137-183. 